\title{
Profile distribution of soil organic carbon fractions under different landforms in the Meghalaya plateau of India
}

K. K. Mourya 网

ICAR-National Bureau of Soil Survey and Land Use Planning, Regional Centre, Jorhat, Assam.

R. K. Jena

ICAR-Indian Institute of Water Management, Bhubaneswar, Odisha

P. Ray

ICAR-Indian Agricultural Research Institute, New Delhi

\section{S. Ramachandran}

ICAR- Indian Institute of Horticultural Research, Bengaluru, Karnataka

G. K. Sharma

ICAR-Indian Institute of Soil and Water Conservation, Research Centre, Kota, Rajasthan

S. Hota

ICAR-National Bureau of Soil Survey and Land Use Planning, Regional Centre, Jorhat, Assam

S. K. Ray

ICAR-National Bureau of Soil Survey and Land Use Planning, Regional Centre, Jorhat, Assam

\begin{tabular}{|c|c|}
\hline ARTICLE INFO & ABSTRACT \\
\hline $\begin{array}{l}\text { Received : } 29 \text { April } 2021 \\
\text { Revised : } 22 \text { May } 2021 \\
\text { Accepted : } 08 \text { July } 2021 \\
\text { Available online: } 19 \text { November } 2021 \\
\text { Key Words: } \\
\text { Carbon density } \\
\text { Landforms } \\
\text { Organic carbon fractions } \\
\text { Soil organic carbon }\end{array}$ & $\begin{array}{l}\text { Assessment of organic carbon fractions in soil provides the basis to ascertain } \\
\text { vulnerability of an ecosystem to climate change. In the present study, we } \\
\text { assessed SOC fractions in four pedons under contrasting landforms i.e., } \\
\text { denudational low hill, upper plateau, lower plateau and valley in the } \\
\text { Meghalaya plateau, India. Results indicated that soils of the studied pedons } \\
\text { were acidic in nature, low in cation exchange capacity and base saturation. } \\
\text { Further, surface }(0-30 \mathrm{~cm}) \text { soils were high in Walkley Black C (WBC) content } \\
(0.83-1.13 \%) \text { in the studied pedons located under different landforms. The } \\
\text { density of very labile carbon (VLC) fraction up to a depth of } 150 \mathrm{~cm} \text { was } \\
\text { highest }\left(49.22 \mathrm{Mg} \text { ha }^{-1}\right) \text { in pedon } 2 \text { (P2) located in the upper plateau under } \\
\text { shifting cultivation while that of less labile carbon (LLC) was highest (50.25 } \\
\left.\text { Mg ha }{ }^{-1}\right) \text { in pedon } 4 \text { (P4) in the valley under paddy cultivation. Higher } \\
\text { densities of WBC and LLC in the valley (P4) as compared to other landforms } \\
\text { in the study area indicate higher carbon sequestration potential of valley soil. }\end{array}$ \\
\hline
\end{tabular}

\section{Introduction}

Soil organic carbon (SOC) forms the largest terrestrial pool which plays an important role in soil fertility and carbon sequestration. The global SOC stock is estimated at $1500 \mathrm{Pg}$ in the upper $1 \mathrm{~m}$ soil depth and it is three times of the atmospheric pool and two times of the biotic pool (Lal, 2008). The SOC plays an important role in carbon cycling, soil aggregate formation, water retention and soil biodiversity; and affects various physical, chemical, and biological properties of soil (Smith et al., 2008; Singh et al., 2018). It has been recognized that any small change in the SOC stock can significantly affect the atmospheric $\mathrm{CO}_{2}$ concentration and leads to global warming (Dhillon and von Wuehlisch, 2013). The SOC stocks in soils are influenced by soil types, climate, vegetation, topography and land use management (Singh et al., 2011; Singh and Benbi, 2018; Reza et al., 2019). Conversion of forest and grassland into agricultural lands may lead to depletion of SOC stock (Chaudhury et al., 2016; Ghosh et al., 2020) mainly due to less organic matter input (Singh et al., 2011) and exposure of protected SOC by tillage operations to microbial decomposition (Pandey et al., 2010). It is 
reported that adoption of appropriate land use and soil management practices may augment C sequestration in soil (Powlson et al., 2011; Singh and Benbi, 2018). Therefore, identification of appropriate land use system under appropriate landscape position with high carbon sequestration potential is of tremendous importance in view of climate change.

Soil organic matter (SOM) is composed of various materials of different biochemistry which vary in their rate of decomposition by microorganisms. Therefore, quantitative knowledge of SOC fractions is important to understand the SOM decomposition and stabilization process in the soil (Poeplau et al., 2018). Based on residence time, SOC is categorized into labile and non-labile carbon fractions (Chan et al., 2001). The easily decomposable organic matter which has rapid turnover rates called labile carbon fraction and it plays an important role in nutrient cycling (Majumdar et al., 2008). On the other hand, non-labile or recalcitrant fraction of SOC is highly resistant to microbial decomposition and remains unaffected by management changes. This fraction is considered to be important for the soil carbon sequestration (Paul et al., 2001). Among different physical, chemical and biological methods of separation of SOC fractions, chemical methods are the most common. Chemical methods use different concentrations of acids to hydrolyse the carbon (Paul et al., 2001), digest the soil with permanganate (Weil et al., 2003) or extract it with hot water (Gregorich et al., 2003). Chemical methods are based on the principle that SOM fraction which is readily decomposed by the microbial enzyme is also easily hydrolyzed by acids or solubilized by hot water (McLauchlan et al., 2004). Several studies have reported that subsurface layer (below $15 \mathrm{~cm}$ ) store more than $70 \%$ of SOC (Jobbagy and Jackson, 2000) and considered more important for $\mathrm{C}$ sequestration due to the fact that SOC in subsoil is more stable and resistant to microbial decomposition (Datta et al., 2015; Ghosh et al., 2020). Thus, the details of SOC distribution within the soil profile are important for carbon budgeting and for the management of ecosystem services (Kukal et al., 2014). Besides, quantification of SOC stocks and its fractions under differential landforms and land uses helps in identifying the suitable and potential niche area for sequestration of SOC. Earlier, Gupta and Rao
(1994) quantified the SOC stock of Indian soils utilizing the data from 48 benchmark soil series across the country and reported the SOC stock at $24.3 \mathrm{Pg}$ ranging from surface to average depth of $0.44-1.86 \mathrm{~m}$. Bhattacharyya et al. (2000) estimated the SOC stock of Indian soils to $29.97 \mathrm{Pg}$ in the $0-150 \mathrm{~cm}$ depth from 60 Agro-Ecological Sub Regions (AESRs) using the point data from benchmark soils and other soils reported in the literature in the AESRs.

North Eastern Region (NER) of India has wide variations in climate and physiography which supports the growth of dense vegetation. Soils of the NER are very high in SOC content and estimated to $>1 \%$ in $98.54 \%$ area and $>2.5 \%$ in $14.4 \%$ area in the surface layer. Similarly, $76.5 \%$ area had SOC density of $20-40 \mathrm{Mg} / \mathrm{ha}$, and $8 \%$ area had a very high SOC density of $40-60 \mathrm{Mg} / \mathrm{ha}$ (Chaudhuri et al., 2013). The NER is considered as green belt due to its relatively high SOC content (Bhattacharyya et al., 2008). However, accelerated deforestation, unscientific land-use, and reduced fallow period under shifting cultivation are of major concern in relation to their effects on SOC stocks of NER (Ray et al., 2021a). Erosion and redistribution of soil particles influence not only the quantity of SOC but also its quality along hill slopes (Singh and Benbi, 2018). At the erosional portions of the landscape, exposed mineral surfaces accumulate fresh and labile $\mathrm{C}$ which become part of new top soil (Fissore et al., 2017) whereas at depositional portions $\mathrm{C}$ is protected from decomposition with longer mean residence time (Doetterl et al., 2012). Bhattacharyya et al. (2010) suggested for maintaining the threshold level of SOC stocks ranging from $50-60 \mathrm{Mg} / \mathrm{ha}$ in the areas under the green belt for the protection of natural ecosystem. However, information is very limited on the depth distribution of SOC and its fractions under different landform positions in the NER. Therefore, the present study was undertaken to quantify the profile distribution of different SOC fractions under contrasting landforms in a part of the Meghalaya plateau, Northeastern India.

\section{Material and Methods}

The study area comes under per-humid sub-tropical Northeastern hill region of India. For the present research work, soil samples were collected from different soil depth up to a depth of $150 \mathrm{~cm}$ from 
representative pedons in contrasting landforms in the Jirang block of Ri-Bhoi district, Meghalaya. Detailed site characteristics of the soils are given in Table 1. For determining bulk density (BD) of soil, samples were collected from each depth using the soil core sampler during soil sampling. The collected soil samples were air-dried, grounded, passed through a $2 \mathrm{~mm}$ sieve and used for characterization of different physical and chemical properties of soil. A part of the soil sample was finely grounded and completely passed through 100 mesh sieves for the determination of SOC. Soil BD was determined by undisturbed core method (Blake and Hartge, 1986). The soil samples were analyzed for important physical and chemical properties following standard procedures (Jackson, 1973). The concentration of SOC (WBC) of each of the soil samples was determined through the wet oxidation method (Walkley and Black, 1934). The concentration of organic carbon fractions was determined by using 5, 10, and $20 \mathrm{~mL}$ of concentrated $\mathrm{H}_{2} \mathrm{SO}_{4}$ which corresponds to the acidaqueous solution of $12 \mathrm{~N}, 18 \mathrm{~N}$, and $24 \mathrm{~N} \mathrm{H}_{2} \mathrm{SO}_{4}$ (Chan et al., 2001). Organic $\mathrm{C}$ oxidized by $12 \mathrm{~N}$ $\mathrm{H}_{2} \mathrm{SO}_{4}$ has been considered as a very labile $\mathrm{C}$ (VLC) fraction; whereas the difference between $\mathrm{C}$ oxidized by $18 \mathrm{~N} \mathrm{H}_{2} \mathrm{SO}_{4}$ and $12 \mathrm{~N} \mathrm{H}_{2} \mathrm{SO}_{4}$ has been considered as labile $\mathrm{C}$ (LC) fraction. Besides, the difference between $\mathrm{C}$ oxidized by $24 \mathrm{~N} \mathrm{H}_{2} \mathrm{SO}_{4}$ and $18 \mathrm{~N} \mathrm{H}_{2} \mathrm{SO}_{4}$ has been considered as less-labile $\mathrm{C}$ (LLC) fraction. The depth-wise density of each SOC fraction was calculated using the following equation:

SOC density $\left(\mathrm{Mg} \mathrm{ha}^{-1}\right)=\operatorname{SOC}(\%) \times \mathrm{BD}\left(\mathrm{Mg} \mathrm{m}^{-3}\right) \times$ soil depth $(\mathrm{m}) \times 100$

SOC density for entire soil profile (up to $150 \mathrm{~cm}$ depth) was determined by summing up the SOC density of all the soil horizons of the profile.

Table 1: Soil type and site characteristics of the studied pedons (Jena et al., 2015)

\begin{tabular}{|c|c|c|c|c|c|}
\hline Pedon No & Soil type & Landform & Slope gradient (\%) & Drainage & Present land use \\
\hline P1 & $\begin{array}{c}\text { Typic } \\
\text { Hapludults }\end{array}$ & Denudational low hill & $25-33$ & Well & Forest \\
\hline $\mathrm{P} 2$ & $\begin{array}{c}\text { Typic } \\
\text { Kandiudults }\end{array}$ & Upper plateau & $10-15$ & Well & $\begin{array}{c}\text { Shifting } \\
\text { cultivation }\end{array}$ \\
\hline P3 & $\begin{array}{c}\text { Fluventic } \\
\text { Endoaquepts }\end{array}$ & Lower plateau & $5-8$ & $\begin{array}{l}\text { Imperfectly } \\
\text { drained }\end{array}$ & Paddy \\
\hline P4 & $\begin{array}{c}\text { Typic } \\
\text { Endoaqualss }\end{array}$ & Valley & $1-3$ & $\begin{array}{l}\text { Imperfectly } \\
\text { drained }\end{array}$ & Paddy \\
\hline
\end{tabular}

\section{Results and Discussion}

Soil physical and chemical properties: Data on important soil physical and chemical properties are presented in Table 2 . The sand content in the soils under different landforms varied from $11.36 \%$ to $42.13 \%$ in surface layers $(0-30 \mathrm{~cm})$ whereas it varied from $7.78 \%$ to $70.96 \%$ in the sub-surface layers. Sand content decreased with depth in the highly weathered soil of pedon $\mathrm{P} 1$ on the denudational low hill and pedon P2 on the upper plateau and increased with depth in the pedon P3 on the lower plateau and irregular pattern was recorded in pedon P4 on the valley. Silt content in the surface layer varied from $19.37 \%$ to $45.07 \%$, whereas in sub-surface layers it varied from 10.57 $\%$ to $43.63 \%$. The clay content in soils under different landforms varied from $38.50 \%$ to 43.87 $\%$ in $0-30 \mathrm{~cm}$ depth; $36.50 \%$ to $60.00 \%$ in $30-60$ $\mathrm{cm} ; 23.45 \%$ to $57.30 \%$ in $60-90 \mathrm{~cm} ; 18.48 \%$ to
$60.47 \%$ in $90-150 \mathrm{~cm}$ soil depth. An increase in the clay content with depth in the pedons P1 and P2 indicated the illuviation of clay in the denudational low hill and upper plateau (Jena et al., 2016).

In the $0-30 \mathrm{~cm}$ soil depth, variation in bulk density (BD) was not observed among the soils under different landforms while at subsurface BD varied from $1.18 \mathrm{Mg} \mathrm{m}^{-3}$ to $1.54 \mathrm{Mg} \mathrm{m}^{-3}$. An increase in the bulk density with depth was observed in pedon P3 on the lower plateau; the irregular pattern was observed in pedon P2 on the upper plateau and P4 on the valley, while subsurface has a lower bulk density in pedon P1 on the denudational low hill. An increase in the soil bulk density in the lower depth of soil profile was due to the low organic matter content and compaction from the pressure of upper layers (Singh and Agrawal, 2005). Soil reaction ( $\mathrm{pH}$ 1:2.5 soil:water ratio) of the pedons 
Table 2: Important physical and chemical properties of the studied pedons

\begin{tabular}{|c|c|c|c|c|c|c|c|c|c|}
\hline $\begin{array}{l}\text { Pedon } \\
\text { No } \\
\end{array}$ & $\begin{array}{c}\text { Sand } \\
(\%)\end{array}$ & $\begin{array}{l}\text { Silt } \\
(\%)\end{array}$ & $\begin{array}{l}\text { Clay } \\
(\%)\end{array}$ & $\begin{array}{c}\text { BD } \\
\left(\mathrm{Mgm}^{-3}\right)\end{array}$ & pH & $\begin{array}{c}\text { WBC } \\
(\%)\end{array}$ & $\begin{array}{c}\text { CEC } \\
\left(\mathrm{cmol}_{c} \mathrm{~kg}^{-1}\right)\end{array}$ & $\begin{array}{l}\text { Clay CEC } \\
\left(\mathrm{cmol}_{c} \mathrm{~kg}^{-1}\right)\end{array}$ & $\begin{array}{l}\text { BS } \\
(\%)\end{array}$ \\
\hline \multicolumn{10}{|c|}{$0-30 \mathrm{~cm}$} \\
\hline P1 & 22.03 & 34.10 & 43.87 & 1.32 & 5.3 & 0.83 & 9.22 & 22 & 37.56 \\
\hline $\mathbf{P 2}$ & 42.13 & 19.37 & 38.50 & 1.33 & 4.8 & 1.00 & 7.61 & 20 & 13.76 \\
\hline P3 & 11.36 & 45.07 & 43.57 & 1.35 & 5.1 & 1.13 & 11.92 & 27 & 31.56 \\
\hline P4 & 16.80 & 44.70 & 38.50 & 1.33 & 4.9 & 1.00 & 10.19 & 26 & 40.13 \\
\hline Mean & 23.08 & 35.81 & 41.11 & 1.33 & 5.0 & 0.99 & 9.73 & 24 & 30.75 \\
\hline \multicolumn{10}{|c|}{$30-60 \mathrm{~cm}$} \\
\hline P1 & 10.12 & 29.88 & 60.00 & 1.25 & 5.6 & 0.47 & 10.35 & 17 & 40.12 \\
\hline $\mathbf{P 2}$ & 35.00 & 17.90 & 47.10 & 1.27 & 4.8 & 0.51 & 7.07 & 15 & 12.64 \\
\hline P3 & 14.63 & 41.87 & 43.50 & 1.43 & 5.5 & 0.50 & 10.29 & 24 & 44.33 \\
\hline P4 & 23.30 & 40.20 & 36.50 & 1.54 & 5.9 & 0.38 & 9.41 & 26 & 55.00 \\
\hline Mean & 20.76 & 32.46 & 46.78 & 1.37 & 5.4 & 0.47 & 9.28 & 20 & 38.02 \\
\hline \multicolumn{10}{|c|}{$60-90 \mathrm{~cm}$} \\
\hline P1 & 7.78 & 34.92 & 57.30 & 1.25 & 5.5 & 0.37 & 10.23 & 18 & 38.85 \\
\hline P2 & 33.94 & 19.26 & 46.80 & 1.18 & 4.8 & 0.35 & 6.76 & 14 & 12.70 \\
\hline $\mathbf{P 3}$ & 55.60 & 20.95 & 23.45 & 1.46 & 5.5 & 0.24 & 5.79 & 24 & 51.26 \\
\hline $\mathbf{P 4}$ & 10.70 & 43.63 & 45.67 & 1.50 & 5.6 & 0.41 & 10.68 & 23 & 76.73 \\
\hline Mean & 27.01 & 29.69 & 43.30 & 1.35 & 5.3 & 0.34 & 8.37 & 20 & 44.89 \\
\hline \multicolumn{10}{|c|}{$90-150 \mathrm{~cm}$} \\
\hline P1 & 8.13 & 31.40 & 60.47 & 1.25 & 5.5 & 0.32 & 10.65 & 18 & 46.22 \\
\hline P2 & 37.22 & 19.57 & 43.21 & 1.23 & 5.2 & 0.25 & 6.19 & 14 & 11.87 \\
\hline $\mathbf{P 3}$ & 70.96 & 10.57 & 18.48 & 1.54 & 5.5 & 0.20 & 4.83 & 25 & 43.36 \\
\hline P4 & 11.53 & 42.63 & 45.83 & 1.48 & 5.7 & 0.28 & 11.20 & 24 & 64.66 \\
\hline Mean & 31.96 & 26.04 & 42.00 & 1.38 & 5.5 & 0.26 & 8.22 & 20 & 41.53 \\
\hline
\end{tabular}

varied from 4.8 to 5.3 in $0-30 \mathrm{~cm} ; 4.8$ to 5.9 in 30 $60 \mathrm{~cm} ; 4.8$ to 5.6 in $60-90 \mathrm{~cm}$ and $5.2-5.7$ in $90-150$ $\mathrm{cm}$ soil depth. In general, the soil $\mathrm{pH}$ increased in all the pedons with depth which might be due to the leaching and accumulation of basic cations in the lower depth (Datta et al., 2015). Soil reaction was acidic in all the studied pedons on different landforms. High annual rainfall in the study area under per-humid climatic condition and associated leaching of bases from soil are attributed to the acidic soil reaction (Bandyopadhyay et al., 2018). Highest content of WBC for surface soil $(0-30 \mathrm{~cm})$ was observed in pedon P3 on the lower plateau and the mean value was $0.99 \%$ indicating accumulation of carbon in the surface layer. The WBC content decreased in all the pedons with depth and mean values from surface to subsoil were $0.99,0.47,0.34$ and $0.26 \%$ for $0-30,30-60,60-90$ and $90-150 \mathrm{~cm}$ soil depth, respectively. Jena et al. (2015) also reported medium $(40 \%$ area) to high $(60 \%$ area) WBC content in the surface layer of Jirang block of
Ri-Bhoi district of Meghalaya. A decrease in the WBC with depth in all the pedons might be due to the less organic matter input in the lower layers (Jobbagy and Jackson, 2000). Cation exchange capacity (CEC) varied from 7.61 to $11.92 \mathrm{cmol}_{\mathrm{c}} \mathrm{kg}^{-1}$ in $0-30 \mathrm{~cm} ; 7.07$ to $10.35 \mathrm{cmol}_{\mathrm{c}} \mathrm{kg}^{-1}$ in $30-60 \mathrm{~cm}$; 5.79 to $10.68 \mathrm{cmol}_{\mathrm{c}} \mathrm{kg}^{-1}$ in $60-90 \mathrm{~cm}$; and 4.83 to $11.20 \mathrm{cmol}_{\mathrm{c}} \mathrm{kg}^{-1}$ in $90-150 \mathrm{~cm}$ soil depth. The values of CEC decreased with depth in pedons P2 and $\mathrm{P} 3$; increased with depth in pedon $\mathrm{P} 1$ and the irregular pattern was observed in case of pedon P4. Variation in CEC might be due to the variation in clay content, presence of pseudo-aggregates of sesquioxides, and coating of clay minerals with amorphous oxides of iron and aluminium (Liu et al., 2020). Clay CEC ranged from 14 to 27 $\mathrm{cmol}_{\mathrm{C}} \mathrm{kg}^{-1}$ clay in the studied pedons. The clay CEC values less than 16 indicates the dominance of low activity clay in soil (Sarkar et al., 2002; Ray et al., 2021b), which was associated with pedon P2. Base saturation (BS) varied from 13.76 to $40.13 \%$ in 0 - 
$30 \mathrm{~cm} ; 12.64$ to $55.00 \%$ in $30-60 \mathrm{~cm} ; 12.70$ to $76.73 \%$ in $60-90 \mathrm{~cm}$; and 11.87 to $64.66 \%$ in 90 $150 \mathrm{~cm}$ soil depth. BS increased with depth in pedons P3 and P4 up to $90 \mathrm{~cm}$; decreased with depth in pedon P2 while irregular pattern was observed in pedon P1.

SOC fractions: Data of the SOC fractions is presented in the Table 3. The mean values of VLC, LC and LLC in the studied pedons were $0.41,0.15$ and $0.43 \%$, respectively in the surface $(0-30 \mathrm{~cm})$ layer and decreased to $0.11,0.04$ and $0.12 \%$, respectively in $90-150 \mathrm{~cm}$ soil depth. Among the different SOC fractions LC was lowest in all the studied pedons. A decrease in SOC fractions with depth might be due to the less organic matter input in the lower layers (Jobbagy and Jackson, 2000). Slope of the landforms is one of the important factors governing runoff and soil erosion, and thereby affecting SOC fractions in soils under different landforms (Reza et al., 2020).

Table 3: Depth wise soil organic carbon (SOC) fractions in the studied pedons

\begin{tabular}{|c|c|c|c|c|c|c|}
\hline \multirow{2}{*}{ Pedon No } & \multicolumn{3}{|c|}{$0-30 \mathrm{~cm}$} & \multicolumn{3}{|c|}{$30-60 \mathrm{~cm}$} \\
\hline & VLC (\%) & LC (\%) & LLC (\%) & VLC (\%) & LC (\%) & LLC (\%) \\
\hline $\mathrm{P} 1$ & 0.31 & 0.11 & 0.41 & 0.20 & 0.08 & 0.19 \\
\hline P2 & 0.52 & 0.05 & 0.43 & 0.29 & 0.08 & 0.14 \\
\hline P3 & 0.43 & 0.24 & 0.45 & 0.14 & 0.13 & 0.23 \\
\hline $\mathrm{P} 4$ & 0.38 & 0.19 & 0.43 & 0.15 & 0.06 & 0.17 \\
\hline \multirow[t]{2}{*}{ Mean } & 0.41 & 0.15 & 0.43 & 0.19 & 0.09 & 0.18 \\
\hline & \multicolumn{3}{|c|}{$60-90 \mathrm{~cm}$} & \multicolumn{3}{|c|}{$90-150 \mathrm{~cm}$} \\
\hline $\mathrm{P} 1$ & 0.17 & 0.07 & 0.14 & 0.15 & 0.01 & 0.16 \\
\hline P2 & 0.21 & 0.05 & 0.09 & 0.14 & 0.07 & 0.04 \\
\hline P3 & 0.08 & 0.05 & 0.11 & 0.05 & 0.03 & 0.11 \\
\hline P4 & 0.13 & 0.04 & 0.24 & 0.09 & 0.03 & 0.16 \\
\hline Mean & 0.15 & 0.05 & 0.14 & 0.11 & 0.04 & 0.12 \\
\hline
\end{tabular}

VLC-very labile C; LC-labile C; LLC-less labile C

The density of the SOC fractions varied with landform and soil depth (Table 4). In the $0-30 \mathrm{~cm}$ soil depth VLC density varied from $12.40 \mathrm{Mg} \mathrm{ha}^{-1}$ in the pedon $\mathrm{P} 1$ on the denudational low hill to $20.67 \mathrm{Mg} \mathrm{ha}^{-1}$ in case of pedon P2 on the upper plateau. The density of LC fraction varied from $2.13 \mathrm{Mg} \mathrm{ha}^{-1}$ in pedon P2 on the upper plateau to $9.80 \mathrm{Mg} \mathrm{ha}^{-1}$ in pedon P3 on the lower plateau. The density of the LLC fraction varied from $16.15 \mathrm{Mg}$ $\mathrm{ha}^{-1}$ in pedon $\mathrm{P} 1$ on the denudational low hill to 18.09 $\mathrm{Mg} \mathrm{ha}^{-1}$ in pedon P3 on the lower plateau. The WBC density in the surface layer varied from $33.05 \mathrm{Mg} \mathrm{ha}^{-1}$ in pedon P1 on the denudational low hill to $45.44 \mathrm{Mg} \mathrm{ha}^{-1}$ in the pedon P3 on the lower plateau. In the 30-60 $\mathrm{cm}$ soil depth density of VLC varied from $5.93 \mathrm{Mg} \mathrm{ha}^{-1}$ in case of pedon P3 on the lower plateau to $10.90 \mathrm{Mg} \mathrm{ha}^{-1}$ in the pedon P2 on the upper plateau. The density of LC varied from $2.77 \mathrm{Mg} \mathrm{ha}^{-1}$ in pedon $\mathrm{P} 4$ on the valley to the $5.47 \mathrm{Mg} \mathrm{ha}^{-1}$ in pedon P3 on the lower plateau. The density of LLC varied from $5.49 \mathrm{Mg} \mathrm{ha}^{-1}$ in pedon $\mathrm{P} 2$ on the upper plateau to the $10.04 \mathrm{Mg} \mathrm{ha}^{-1}$ in pedon P3 on the lower plateau. WBC density varied from $17.54 \mathrm{Mg} \mathrm{ha}^{-1}$ in pedon $\mathrm{P} 4$ on the valley to the $21.44 \mathrm{Mg} \mathrm{ha}^{-1}$ in pedon P3 on the lower plateau.

In the $60-90 \mathrm{~cm}$ soil depth density of VLC varied from $3.55 \mathrm{Mg} \mathrm{ha}^{-1}$ in pedon P3 on the lower plateau to $7.34 \mathrm{Mg} \mathrm{ha}^{-1}$ in pedon $\mathrm{P} 2$ on the upper plateau. The density of LC varied from $1.65 \mathrm{Mg} \mathrm{ha}^{-1}$ in pedon $\mathrm{P} 4$ on the valley to $2.48 \mathrm{Mg} \mathrm{ha}^{-1}$ in pedon $\mathrm{P} 1$ on the denudational low hill. The density of LLC varied from $3.25 \mathrm{Mg} \mathrm{ha}^{-1}$ in pedon P2 on the upper plateau to $10.66 \mathrm{Mg} \mathrm{ha}^{-1}$ in pedon $\mathrm{P} 4$ on the valley. WBC density varied from $10.44 \mathrm{Mg} \mathrm{ha}^{-1}$ in pedon P3 to $18.32 \mathrm{Mg} \mathrm{ha}^{-1}$ in pedon P4 on the valley. In the $90-150 \mathrm{~cm}$ soil depth density of VLC varied from 5.03 $\mathrm{Mg} \mathrm{ha}^{-1}$ in pedon P3 on lower plateau to 11.28 $\mathrm{Mg} \mathrm{ha}^{-1}$ in pedon $\mathrm{P} 1$ on the denudational low hill. The density of LC varied from $0.85 \mathrm{Mg} \mathrm{ha}^{-1}$ in pedon $\mathrm{P} 1$ on the denudational low hill to $5.27 \mathrm{Mg}$ $\mathrm{ha}^{-1}$ in pedon P2 on the upper plateau. LLC density varied from $3.16 \mathrm{Mg} \mathrm{ha}^{-1}$ in pedon $\mathrm{P} 2$ on the upper plateau to the $14.54 \mathrm{Mg} \mathrm{ha}^{-1}$ in pedon $\mathrm{P} 4$ on the valley. WBC density varied from $18.23 \mathrm{Mg} \mathrm{ha}^{-1}$ in 
Table 4: Depth wise density of soil organic carbon (SOC) fractions in the studied pedons

\begin{tabular}{|c|c|c|c|c|c|c|c|c|}
\hline \multirow{2}{*}{$\begin{array}{l}\text { Pedon } \\
\text { No }\end{array}$} & \multicolumn{4}{|c|}{$0-30 \mathrm{~cm}$} & \multicolumn{4}{|c|}{$30-60 \mathrm{~cm}$} \\
\hline & $\begin{array}{c}\text { VLC } \\
\left(\mathrm{Mg} \mathrm{ha}^{-1}\right)\end{array}$ & $\begin{array}{c}\text { LC (Mg } \\
\left.\mathrm{ha}^{-1}\right)\end{array}$ & $\begin{array}{c}\text { LLC (Mg } \\
\left.\text { ha }^{-1}\right)\end{array}$ & $\begin{array}{c}\text { WBC } \\
\left(\mathrm{Mg} \mathrm{ha}^{-1}\right)\end{array}$ & $\begin{array}{c}\text { VLC } \\
\left(\mathrm{Mg} \mathrm{ha}^{-1}\right)\end{array}$ & $\begin{array}{c}\text { LC (Mg } \\
\left.h^{-1}\right)\end{array}$ & $\begin{array}{c}\text { LLC (Mg } \\
\left.\mathrm{ha}^{-1}\right)\end{array}$ & $\begin{array}{c}\text { WBC } \\
\left(\mathrm{Mg} \mathrm{ha}^{-1}\right)\end{array}$ \\
\hline P1 & 12.40 & 4.51 & 16.15 & 33.05 & 7.43 & 3.15 & 7.05 & 17.63 \\
\hline $\mathrm{P} 2$ & 20.67 & 2.13 & 17.07 & 39.87 & 10.90 & 3.05 & 5.49 & 19.44 \\
\hline P3 & 17.55 & 9.80 & 18.09 & 45.44 & 5.93 & 5.47 & 10.04 & 21.44 \\
\hline P4 & 15.20 & 7.60 & 17.20 & 40.00 & 6.92 & 2.77 & 7.85 & 17.54 \\
\hline \multirow[t]{2}{*}{ Mean } & 16.45 & 6.01 & 17.13 & 39.59 & 7.79 & 3.61 & 7.61 & 19.01 \\
\hline & \multicolumn{4}{|c|}{$60-90 \mathrm{~cm}$} & \multicolumn{4}{|c|}{$90-150 \mathrm{~cm}$} \\
\hline P1 & 6.30 & 2.48 & 5.25 & 14.03 & 11.28 & 0.85 & 11.99 & 24.11 \\
\hline $\mathrm{P} 2$ & 7.34 & 1.76 & 3.25 & 12.35 & 10.31 & 5.27 & 3.16 & 18.74 \\
\hline P3 & 3.55 & 2.24 & 4.65 & 10.44 & 5.03 & 2.77 & 10.43 & 18.23 \\
\hline $\mathrm{P} 4$ & 6.01 & 1.65 & 10.66 & 18.32 & 7.86 & 2.67 & 14.54 & 25.07 \\
\hline Mean & 5.80 & 2.03 & 5.95 & 13.78 & 8.62 & 2.89 & 10.03 & 21.54 \\
\hline
\end{tabular}

VLC-very labile C; LC-labile C; LLC-less labile C; WBC-Walkley Black C

Table 5: Density of SOC fractions in the studied pedons up to $150 \mathrm{~cm}$ depth

\begin{tabular}{|c|c|c|c|c|}
\hline Pedon No & $\operatorname{VLC}\left(\mathrm{Mg} \mathrm{ha}^{-1}\right)$ & $\mathrm{LC}\left(\mathrm{Mg} \mathrm{ha}^{-1}\right)$ & $\operatorname{LLC}\left(\mathrm{Mg} \mathrm{ha}^{-1}\right)$ & WBC $\left(\mathrm{Mg} \mathrm{ha}^{-1}\right)$ \\
\hline $\mathrm{P} 1$ & 37.40 & 10.98 & 40.44 & 88.81 \\
\hline $\mathrm{P} 2$ & 49.22 & 12.22 & 28.96 & 90.40 \\
\hline P3 & 32.06 & 20.28 & 43.21 & 95.55 \\
\hline P4 & 35.99 & 14.69 & 50.25 & 100.93 \\
\hline Mean & 38.67 & 14.54 & 40.71 & 93.92 \\
\hline
\end{tabular}

VLC-very labile C; LC- labile C; LLC-less labile C; WBC- Walkley Black C

pedon P3 on the lower plateau to $25.07 \mathrm{Mg} \mathrm{ha}^{-1}$ in pedon $\mathrm{P} 4$ on the valley. The overall distribution of VLC, LC, LLC and WBC density up to $150 \mathrm{~cm}$ soil depth is presented in the Table 5. The density of VLC ranged from $32.06 \mathrm{Mg} \mathrm{ha}^{-1}$ in case of pedon P3 on the lower plateau to $49.22 \mathrm{Mg} \mathrm{ha}^{-1}$ in pedon $\mathrm{P} 2$ on the upper plateau with the mean value of $38.67 \mathrm{Mg} \mathrm{ha}^{-1}$. The density of LC varied from $10.98 \mathrm{Mg} \mathrm{ha}^{-1}$ in pedon $\mathrm{P} 1$ on the denudational low hill to $20.28 \mathrm{Mg} \mathrm{ha}^{-1}$ under pedon P3 on the lower plateau. The density of LLC varied from $28.96 \mathrm{Mg}$ $\mathrm{ha}^{-1}$ in pedon $\mathrm{P} 2$ on the upper plateau to $50.25 \mathrm{Mg}$ $\mathrm{ha}^{-1}$ under the pedon $\mathrm{P} 4$ on the valley with the mean value of $40.71 \mathrm{Mg} \mathrm{ha}^{-1}$. The density of WBC ranged from $88.81 \mathrm{Mg} \mathrm{ha}^{-1}$ in case of pedon $\mathrm{P} 1$ on the denudational low hill to the $100.93 \mathrm{Mg} \mathrm{ha}^{-1}$ in pedon $\mathrm{P} 4$ on the valley with the mean value of $93.92 \mathrm{Mg} \mathrm{ha}^{-1}$. The mean value of the density of the different $\mathrm{OC}$ fractions followed the order as WBC $>$ LLC $>$ VLC $>$ LC across different landforms.

The slope of the landform affects the amount and quality of SOC due to variation in hydrology, solar radiation, and vegetation. In the humid subtropical climate, erosion from the steep slope positions and deposition at the gentle slopes and valley positions are the important factors for redistribution of SOC and other plant nutrients (Reza et al., 2014). Shifting cultivation at the steep slopes in the study area further aggravates the soil erosion. Relatively lower values of WBC density and LLC density in soils on the denudational low hill and upper plateau with higher slope classes might have been due to accelerated erosion (Singh et al., 2011). Shifting cultivation at upper plateau might have exposed the protected carbon for the microbial decomposition due to accelerated soil erosion (Fierer et al., 2003) and dominance of low activity clays in such soil might have hindered the process to form clay humus complex (Singh et al., 2018), which resulted in lower value of LLC density in pedon P2. Relatively higher densities of WBC and LLC in the pedon $\mathrm{P} 4$ on valley might be due the deposition and burial of SOC, and reduced microbial activity under anaerobic condition in paddy cultivation (Fissore et al., 2017). Sahrawat (2004) also reported the accumulation of $\mathrm{OC}$ in the valley under paddy cultivation under temperate climate and poor drainage condition. The revegetation of degraded slopes with increased fallow period under shifting cultivation is one of the important strategies to 
control soil erosion with the recovery of the degraded ecosystem through build-up of recalcitrant pool of organic carbon in soil (Singh and Benbi, 2018).

\section{Conclusion}

Results showed that soils of the studied pedons were high in SOC (WBC) content in the surface layer, acidic in reaction, and have low cation exchange capacity with low base saturation across the landforms. Different SOC fractions were influenced by landform positions and land uses. Relatively higher densities of less labile carbon (LLC) and WBC of soils under lower plateau and

\section{References}

Bandyopadhyay, S., Ray, P., Padua, S., Ramachandran, S., Jena, R. K., Roy, P. D., ... \& Ray, S. K. (2018). Priority Zoning of Available Micronutrients in the Soils of Agroecological Sub-regions of North-East India Using Geospatial Techniques. Agricultural research, 7(2), 200-214.

Bhattacharyya, T., Pal, D. K., Chandran, P., Ray, S. K. Mandal, C., \& Telpande, B. (2008). Soil carbon storage capacity as a tool to prioritize areas for carbon sequestration. Current science, 482-494.

Bhattacharyya, T., Pal, D. K., Mandal, C., \& Velayutham, M. (2000). Organic carbon stock in Indian soils and their geographical distribution. Current Science, 655-660.

Bhattacharyya, T., Sarkar, D., Pal, D. K., Mandal, C., Baruah, U., Telpande, B., \& Vaidya, P. H. (2010). Soil information system for resource management-Tripura as a case study. Current Science, 1208-1217.

Blake, G. R., \& Hartge, K. H. (1986). Bulk density. Methods of soil analysis: Part 1 Physical and mineralogical methods, 5, 363-375.

Chan, K. Y., Bowman, A., \& Oates, A. (2001). Oxidizible organic carbon fractions and soil quality changes in an oxic paleustalf under different pasture leys. Soil Science, 166(1), 61-67.

Choudhury, B. U., Fiyaz, A. R., Mohapatra, K. P., \& Ngachan, S. (2016). Impact of land uses, agrophysical variables and altitudinal gradient on soil organic carbon concentration of North-Eastern Himalayan Region of India. Land Degradation \& Development, 27(4), 1163-1174.

Choudhury, B. U., Mohapatra, K. P., Das, A., Das, P. T., Nongkhlaw, L., Fiyaz, R. A., ... \& Munda, G. C. (2013). Spatial variability in distribution of organic carbon stocks in the soils of North East India. Current Science, 604-614. valley as compared to the soils under denudational low hill and upper plateau indicate that the soil organic carbon in the valley and lower plateau are more protective. Further, relatively higher density of very labile carbon (VLC) in shifting cultivated soils under upper plateau indicates the potential vulnerability of the ecosystem to climate change.

\section{Acknowledgement}

The authors are thankful to Director, ICAR- NBSS and LUP, Nagpur for proving all the needed support to conduct the research and Meghalaya Basin Development Authority, Government of Meghalaya for funding the project.

Datta, A., Basak, N., Chaudhari, S. K., \& Sharma, D. K. (2015). Soil properties and organic carbon distribution under different land uses in reclaimed sodic soils of NorthWest India. Geoderma Regional, 4, 134-146.

Dhillon, R. S., \& von Wuehlisch, G. (2013). Mitigation of global warming through renewable biomass. Biomass and bioenergy, 48, 75-89.

Doetterl, S., Six, J., Van Wesemael, B., \& Van Oost, K. (2012). Carbon cycling in eroding landscapes: geomorphic controls on soil organic $\mathrm{C}$ pool composition and $\mathrm{C}$ stabilization. Global Change Biology, 18(7), 2218-2232.

Fierer, N., Schimel, J. P., \& Holden, P. A. (2003). Variations in microbial community composition through two soil depth profiles. Soil Biology and Biochemistry, 35(1), 167-176.

Fissore, C., Dalzell, B. J., Berhe, A. A., Voegtle, M., Evans, M., \& Wu, A. (2017). Influence of topography on soil organic carbon dynamics in a Southern California grassland. Catena, 149, 140-149.

Ghosh, A., Das, A., Das, D., Ray, P., Bhattacharyya, R., Biswas, D. R., \& Biswas, S. S. (2020). Contrasting land use systems and soil organic matter quality and temperature sensitivity in North Eastern India. Soil and Tillage Research, 199, 104573.

Gregorich, E. G., Beare, M. H., Stoklas, U., \& St-Georges, P. (2003). Biodegradability of soluble organic matter in maize-cropped soils. Geoderma, 113(3-4), 237-252.

Gupta, R. K., \& Rao, D. L. N. (1994). Potential of wastelands for sequestering carbon by reforestation. Current science, 378-380.

Jackson, M. L. (1973). Soil chemical analysis, pentice hall of India Pvt. Ltd., New Delhi, India, 498, 151-154. 
Jena, R. K., Duraisami, V. P., Sivasamy, R., Shanmugasundaram, R., Krishnan, R., Padua, S., \& Ray, S. K. (2015). Spatial variability of soil fertility parameters in Jirang Block of RiBhoi District, Meghalaya.

Jena, R. K., Duraisami, V. P., Sivasamy, R., Shanmugasundaram, R., Krishnan, R., Padua, S., \& Ray, S. K. (2016). Characterization and classification of soils of Jirang block in Meghalaya plateau.

Jobbágy, E. G., \& Jackson, R. B. (2000). The vertical distribution of soil organic carbon and its relation to climate and vegetation. Ecological applications, 10(2), 423-436.

Kukal, S. S., \& Bawa, S. S. (2014). Soil organic carbon stock and fractions in relation to land use and soil depth in the degraded Shiwaliks hills of lower Himalayas. Land Degradation \& Development, 25(5), 407-416.

Lal, R. (2008). Soils and sustainable agriculture. A review. Agronomy for Sustainable Development, 28(1), 57-64.

Liu, J., Wang, Z., Hu, F., Xu, C., Ma, R., \& Zhao, S. (2020). Soil organic matter and silt contents determine soil particle surface electrochemical properties across a long-term natural restoration grassland. Catena, 190, 104526.

Majumder, B., Mandal, B., \& Bandyopadhyay, P. K. (2008). Soil organic carbon pools and productivity in relation to nutrient management in a 20-year-old rice-berseem agroecosystem. Biology and Fertility of Soils, 44(3), 451-461.

McLauchlan, K. K., \& Hobbie, S. E. (2004). Comparison of labile soil organic matter fractionation techniques. Soil Science Society of America Journal, 68(5), 1616-1625.

Pandey, C. B., Singh, G. B., Singh, S. K., \& Singh, R. K. (2010). Soil nitrogen and microbial biomass carbon dynamics in native forests and derived agricultural land uses in a humid tropical climate of India. Plant and Soil, 333(1), 453-467.

Paul, E. A., Collins, H. P., \& Leavitt, S. W. (2001). Dynamics of resistant soil carbon of Midwestern agricultural soils measured by naturally occurring 14C abundance. Geoderma, 104(3-4), 239-256.

Poeplau, C., Don, A., Six, J., Kaiser, M., Benbi, D., Chenu, C., \& Nieder, R. (2018). Isolating organic carbon fractions with varying turnover rates in temperate agricultural soils-A comprehensive method comparison. Soil Biology and Biochemistry, 125, 10-26.

Powlson, D. S., Whitmore, A. P., \& Goulding, K. W. (2011). Soil carbon sequestration to mitigate climate change: a critical reexamination to identify the true and the false. European Journal of Soil Science, 62(1), 42-55.

Ray, P., Chattaraj, S., Bandyopadhyay, S., Jena, R. K., Singh, S. K., \& Ray, S. K.(2021a) Shifting cultivation, soil degradation and agricultural land use planning in the North-eastern hill region of India using geo-spatial techniques. Land Degradation \& Development.
Ray, P., Gogoi, S. N., Bandyopadhyay, S., Jena, R. K., Ramachandran, S., Sharma, G. K., \& Ray, S. K. (2021b). Soilcum-nutrient management package for achieving high yield and quality of mulberry (Morus indica L.) leaf in acid soil of North Eastern India. Journal of Plant Nutrition, 1-13.

Reza, S. K., Baruah, U., Nath, D. J., Sarkar, D., \& Gogoi, D. (2014). Microbial biomass and enzyme activity in relation to shifting cultivation and horticultural practices in humid subtropical North-Eastern India.

Reza, S. K., Ray, P., Ramachandran, S., Bandyopadhyay, S., Mukhopadhyay, S., Sah, K. D., ... \& Ray, S. K. (2019). Profile distribution of soil organic carbon in major land use systems in Bishalgarh block, Tripura. Journal of the Indian Society of Soil Science, 67(2), 236-239.

Reza, S. K., Ray, P., Ramachandran, S., Jena, R. K., Mukhopadhyay, S., \& Ray, S. K. (2020). Soil Organic Carbon Fractions in Major Land Use Systems in Charilam Block of Tripura. Journal of the Indian Society of Soil Science, 68(4), 458-461.

Sahrawat, K. L. (2004). Organic matter accumulation in submerged soils. Advances in Agronomy, 81, 169-201.

Sarkar, D., Baruah, U., Gangopadhyay, S. K., Sahoo, A. K., \& Velayutham, M. (2002). Characteristics and classification of soils of Loktak catchment area of Manipur for sustainable land use planning. Journal of the Indian Society of Soil Science, 50(2), 196-204.

Singh, I. S., \& Agrawal, H. P. (2005). Characterization, genesis and classification of rice soils of eastern region of Varanasi, Uttar Pradesh. Agropedology, 15(1), 29-38.

Singh, M., Sarkar, B., Sarkar, S., Churchman, J., Bolan, N., Mandal, S., ... \& Beerling, D. J. (2018). Stabilization of soil organic carbon as influenced by clay mineralogy. Advances in agronomy, 148, 33-84.

Singh, P., \& Benbi, D. K. (2018). Soil organic carbon pool changes in relation to slope position and land-use in Indian lower Himalayas. Catena, 166, 171-180.

Singh, S. K., Pandey, C. B., Sidhu, G. S., Sarkar, D., \& Sagar, R. (2011). Concentration and stock of carbon in the soils affected by land uses and climates in the western Himalaya, India. Catena, 87(1), 78-89.

Smith, P., Fang, C., Dawson, J. J., \& Moncrieff, J. B. (2008). Impact of global warming on soil organic carbon. Advances in agronomy, 97, 1-43.

Walkley, A., \& Black, I. A. (1934). An examination of the Degtjareff method for determining soil organic matter, and a proposed modification of the chromic acid titration method. Soil science, 37(1), 29-38.

Weil, R. R., Islam, K. R., Stine, M. A., Gruver, J. B., \& SamsonLiebig, S. E. (2003). Estimating active carbon for soil quality assessment: A simplified method for laboratory and field use. American Journal of Alternative Agriculture, 18(1), 3-17. 